\title{
FUNGSI TENAGA KESEJAHTERAAN SOSIAL DI KECAMATAN POASIA DALAM MENINGKATKAN KESEJAHTERAAN \\ MASYARAKAT
}

Muhammad Ali Badaruddin ${ }^{1}$, Jamaluddin $\operatorname{Hos}^{2}$, Tanzil ${ }^{3}$

${ }^{123}$ Fakultas Ilmu Sosial dan Ilmu Politik Universitas Halu Oleo

E-mail: Muhalibadaruddin05@gmail.com, jamaluddin_hos@uho.ac.id, tanzilsosio@gmail.com

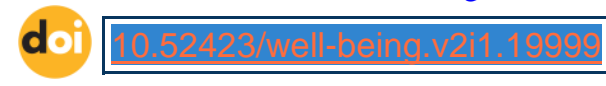

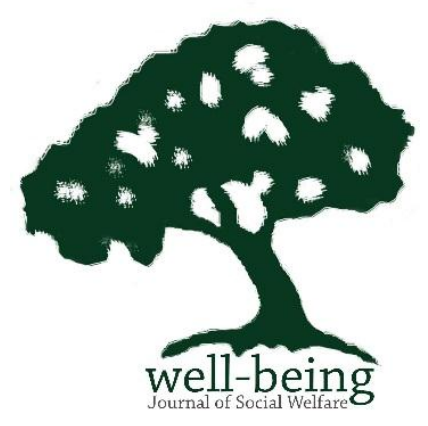

\begin{abstract}
This research was conducted in Poasia District, Kendari City. The objectives of this study were (1) To determine the role of social welfare workers in Poasia District, Kendari City (2) To determine the driving and inhibiting factors of the role of social welfare workers in Poasia District, Kendari City. The research method used is using qualitative research methods, qualitative methods are research methods that produce descriptive data and written or spoken words from people's behavior can be observed, the research technique used is observation / observation, namely the researcher goes directly to the field to obtain data and prepare the tools and materials used at the time of the research. Interviews were conducted to gather information such as the role of social welfare workers and the driving and inhibiting factors in Poasia District, Kendari City. Documentation is done in order to strengthen the data from the results of the interviews conducted in the observation. The technique of determining informants in this research was carried out by purposive sampling. Data were analyzed using data reduction techniques, data presentation, and drawing conclusions. The results of this study indicate that in Poasia District there are still many underprivileged people, then the government provides assistance through the Ministry of Social Affairs for less fortunate families. This assistance is provided through a different home program. This program aims to improve the quality of housing for underprivileged people.
\end{abstract}

Keywords: Improve, Welfare, Society

\section{PENDAHULUAN}

Kemiskinan

merupakan

permasalahan kompleks dan multidimensi serta memiliki dampak sangat luas terhadap kualitas hidup manusia. Kemiskinan adalah situasi serba terbatas yang terjadi bukan atas kehendak orang yang bersangkutan dan ditandai oleh rendahnya tingkat pendidikan, produktivitas kerja, pendapatan, kesehatan dan gizi serta kesejahteraan hidupnya, yang menunjukkan lingkaran ketidakberdayaan. (Damayanti, 2016, hal 34).

Parwoto (Barika,

2013:27) menyatakan bahwa kemiskinan adalah suatu situasi atau kondisi yang dialami oleh seseorang atau kelompok orang yang tidak mampu menyelenggarakan hidupnya sampai suatu taraf yang dianggap manusiawi. (Barika, 2013) Sedangkan menurut Ravallion (Durrotul
Mahsunah,2013:3), kemiskinan adalah kelaparan, tidak memilikitempat tinggal, bila sakit tidak mempunyaidana untuk berobat. (Mahsunah, 2013).

Kemiskinan merupakan masalah yang harus mendapatkan perhatian serius dari pemerintah, karena salah satu ukuran keberhasilan pembangunan adalah berkurangnya angka kemiskinan. Dalam upaya menekan angka kemiskinan pemerintah tentu tidak dapat bekerja sendiri, perlu adanya dukungan dan partisipasi aktif dari masyarakat. Guna terlaksananya program pengentasan kemiskinan yang optimal, pemerintah membutuhkan sumber daya manusia yang berasal dari akar rumput masyarakatdan concern pada masalah sosial. Untuk itu, pada tahun 2009 Pemerintah Pusat melalui Kementerian Sosial membentuk Tenaga Kesejahteraan Sosial Kecamatan (TKSK) 
yang dalam melaksanakan tugasnya akan bersinergi, berjejaring, dan bermitra dengan berbagai Potensi dan Sumber Kesejahteraan Sosial (PSKS).

Dalam penyelenggaraan

kesejahteraan sosial, Tenaga Kesejahteraan Sosial Kecamatan (TKSK) memiliki 3 (tiga) fungsi, yaitu koordinator, administrator, dan fasilitator. Sebagai koordinator, Tenaga Kesejahteraan Sosial Kecamatan (TKSK) melaksanakan fungsifungsi koordinasi yang berkaitan dengan kerjasama, sinergi, integrasi, dan sinkronisasi dengan PSKS, sumber daya manusia kesejahteraan sosial dan berbagai pemangku kepentingan. Dalam fungsinya sebagai administrator, Tenaga Kesejahteraan Sosial Kecamatan (TKSK) melakukan perencanaan dan pengorganisasian,serta melaksanakan dan memantau penyelenggaraan kesejahteraan sosial. Sedangkan fungsi fasilitator dilaksanakan dengan cara melakukan pendampingan sosial secara langsung maupun tidak langsung (Peraturan Menteri Sosial RI Nomor 03 Tahun 2013 Tentang Tenaga Kesejahteraan Sosial Kecamatan).

Menurut Peraturan Menteri Sosial RI No. 108/HUK/2009 tentang Sertifikasi Bagi Pekerja Sosial Profesional dan Tenaga Kesejahteraan Sosial menyatakan bahwa Tenaga Kesejahteraan Sosial adalah mereka yang berlatar belakang pendidikan pekerjaan sosial atau sarjana non pekerjaan sosial yang memiliki pengalaman pelayanan sosial minimal 3 (tiga) tahun dan telah mengikuti pelatihan di bidang kesejahteraan sosial. Keberadaan Tenaga Kesejahteraan Sosial (TKS) dalam penyelenggaraan kesejahteraan sosial sama pentingnya dengan Pekerja Sosial Profesional sebagaimana ditetapkan dalam UU No 11 tahun 2009 tentang Kesejahteran Sosial dan UU 13 tahun 2011 tentang Penanganan Fakir Miskin bahwa TKS adalah salah satu SDM dalam penyelenggaraan kesejahteraan sosial.

\section{METODE PENELITIAN}

Penelitian ini dilaksanakan di Kecamatan Poasia Kota Kendari, Sulawesi Tenggara. Dengan pertimbangan bahwa kecamatan poasia sebagai salah satu kecamatan yang selalu kompak atau aktif dalam menjalankan tugas dan fungsi mereka.

Jenis penelitian ini menggunakan penelitian kualitatif, menurut Bogdan Taylor dalam (Upe, 2016) metedologi penelitian kualitatif sebagai prosedur penelitian yang menghasilkan data deskriptif berupa kata-kata tertulis atau lisan dari orang-orang dan perilaku yang dapat diamati. Menurutnya pendekatan ini diarahkan pada latar dan individu secara menyeluruh (holistic). Sedangkan menurut Sugiyono (2014) metode penelitian kualitatif sering disebut penelitian naturalistik, karena penelitianya dilakukan pada kondisi yang alamiah.

Pemilihan informan dilakukan dengan tujuan Untuk mendapatkan informasi dari berbagai sumber dan menggali informasi yang menjadi dasar penulisan laporan. Oleh karena itu, dalam penelitian ini menggunakan teknik pemilihan informan secara spurposive sampling (pemilihan informan secara sengaja).

Jenis data adalah Data primer adalah data dari penelitian langsung dari sumber asli (tidak melalui perantara). Data primer didapat melalui metode wawancara dan pengamatan langsung (observasi). Fungsi Tenaga Kesejahteraan Sosial Di Kecamatan Poasia Dalam Meningkatkan Kesejahteraan Masyarakat dan data Sekunder data berupa arsip-arsip sebagai data penunjang berlangsung nya penelitian. Kedua data tersebut saling melengkapi dan menunjang, meskipun pada dasarnya kedua data tersebut berdiri sendiri-sendiri. Dalam penelitian Untuk mencapai kelengkapan 
semuanya sangat dibutuhkan, data primer akan memperoleh kelengkapanya apabila ada dan ditunjang dengan data sekunder demikian pula sebaliknya, data sekunder akan mudah didapatkan apabila data primer cukup lengkap dalam menunjang permasalahannya.

Teknik Pengumpulan Data, Teknik observasi yaitu peneliti melakukan pengamatan secara langsung di lapangan tentang Fungsi Tenaga Kesejahteraan Sosial Dikecamatan Poasia Dalam Meningkatkan Kesejahteraan Masyarakat. Teknik wawancara yaitu Tanya jawab yang dilakukan peneliti untuk mengetahui informasi tentang peneliti yang akan dilakukan.dan teknik dokumentasi yaitu mencari data mengenai hal-hal atau variable yang berupa catatan, transkip, buku, arsip, surat kabar, majalah, prasasti, notulen rapat, lengger, agenda, dan sebagainya (Arikunto,2014:274).

Teknik Analisa Data adalah Analisis data dalam penelitian ini adalah teknik penelitian deskriptif kualitatif yaitu proses mencari dan menyusun secara sistematis data yang diperoleh dari hasil wawancara, catatan lapangan, dan dokumentasi, dengan cara mengorganisasikan data kedalam kategori, menjabarkan kedalam unit-unit, melakukan sintesa, menyusun kedalam pola, memilih mana yang penting dan yang akan dipelajari, dan membuat kesimpulan sehingga mudah dipahami oleh diri sendiri maupun orang lain (Sugiyono, 2014). Milles and Huberman 1984 dalam Sugiyono (2014) mengemukakan aktivitas dalam analisis data kualitatif dilakukan secara interaktif dan berlangsung secara terus menerus sampai tuntas, sehingga datannya sudah jenuh.

\section{HASIL DAN PEMBAHASAN}

1. Fungsi Tenaga Kesejahteraan Sosial di Kecamatan Poasia Dalam

\section{Meningkatkan Masyarakat}

A. Fungsi Koordinasi

Melakukan Koordinasi dengan Pihak Dinas Sosial TKSK melakukan pendataan di Kecamatan Poasia bagi keluarga yang kurang mampu, setelah TKSK melakukan pendataan, selanjtnya TKSK mengelompokan data keluarga yang kurang mampu. Kemudian mengkoordinasikannya dengan Dinas Sosial, untuk membuat proposal Permohonan bantuan untuk diusulkan di Kementrian Sosial.

Berikut wawancara dengan Ibu Istiawati selaku tenaga kesejahteraan sosial kecamatan (TKSK).

Jadi dek, setelah kami mengelompokkan data keluarga yang kurang mampu yang mempunyai skil, maka kami sebagai TKSK, langsung membuatkan grub bagi mereka yang mempunyai skil yang sebanyak 10 orang pergrup. Lalu saya membuat proposal permohonan kemudian langsung mengajukan proposal permohonan tersebut kepihak dinas sosial kota kendari agar data keluarga yang kurang mampu yang sudah kami masukkan dalam proposal bisa di usulkan ke kementrian sosial, agar kiranya nama-nama keluarga yang kurang mampu yang sudah kami data bisa diberikan bantuan.

Dari hasil wawancara tersebut maka dapat disimpulkan bahwa, setiap ada keluarga yang kurang mampu, TKSK berperan untuk mengajukan proposal permohonan kepihak dinas sosial. Kemudian pihak dinas sosial kota Kendari dapat mengusulkan proposal tersebut ke kementrian sosial agar keluarga tersebut dapat diberikan bantuan. 
B. Fungsi Administrasi

Pendataan dan Validasi Data Untuk Mengidentivikasi Masalah Untuk Keluarga Yang Kurang Mampu. Pada Tahun 2019 pemerintah melalui Kementrian Sosial memberikan bantuan kepada masyarakat yang kurang mampu. Bantuan tersebut dilasurkan melalui program beda rumah. Program ini bertujuan untuk meningkatkan kulaitas tempat tinggal dari masyarakat yang kurang mampu. Tenaga Kesejahteraan Sosial melalui arahan dari Dinas Sosial melkukan pendataan guna mendapat data penerima. Adapun Kriteria penerima bantauan yaitu a) Masuk kategori fakir miskin dan memiliki Identitas yang berlaku; b) Kepala keluarga atau anggota keluarga yang tidak mempunyai sumber mata pencaharian atau mempunyai mata pencaharian, namun berpenghasilan dibawah UM; c) Kehidupan sehari-sehari masih memerlukan bantuan pangan untuk penduduk miskin (zakat atau raskin); d) Memiliki rumah diatas tanah sendiri yang dibuktikan dengan sertifikat atau surat keterang kepemilikan dari Kelurahan; e) Bersedia tidak menjual atau menyewakan rumah tersebut selama minimal lima tahun setelah menerima bantuan dari Kementrian Sosial.

Hasil pendatan yang dilakukan oleh Tenaga Kesejahteraan Sosial di Kecamatan Poasia bagi keluarga yang kurang mampu berjumalah 58 kepala kaluarga. Berikut wawancara dengan Bapak Yahya (41) selaku tenaga kesejahteraan Sosial Kecamatan (TKSK).

Penjelasan kami dek sebagai TKSK itukan naungan Dinas Sosial untuk melakukan pendataan bagi keluarga yang kurang mampu dalam bantuan bedah rumah dan bantuan sembako, jadi ketika kami mendengar di wilaya kerja kami ada masalah yang menyangkut dengan kesehjateraan masyarakat dalam hal kurangannya ekonomi, kami akan melakukan kordinasi kepada Dinas Sosial untuk melakukan pendataan bagi keluarga yang kurang mampu tersebut. Bantuan tersebut diberikan kepada keluarga yang kurang yaitu bedah rumah dan bantuan sembako agar sedikit membantu perekonomian mereka.

Dari hasil wawancara diatas dapat disimpulkan bahwa TKSK dapat melakukan pendataan, apa bila Dinas Sosial telah mengarahkan untuk melakukan pendataan bantuan bedah rumah dalam keluarga yang kurang mampu. Selain itu Bapak Wirasto Seno Aji (47) selaku tenaga kesejahteraan sosial kecamatan menembahkan bahwa:

Ketika ada kasus diwilayah tempat saya bekerja khususnya keluarga yang kurang mampu, maka saya langsung mendatangi rumah masyarakat tersebut untuk melakukan pendataan, saya biasanya memberikan formulir untuk diisi dan meminta foto kopi KTP dan Kartu Keluarga. Sehingga kami TKSK dapat dengan mudah mambantu.

Dari hasil wawancara diatas dapat disimpulkan bahwa TKSK mengunjungi kelurahan setiap ada permasalahan ditempat ia bekerja untuk melakukan pendataan terhadap masyarakat yang belum mendapatkan bantuan. Kemudian pada saat pendataan sambil melihat kondisi rumah dan lingkungan rumah tempat tinggal masyarakat yang kurang mampu. Dalam pendataan TKSK langsung meminta foto kopi KTP dan Kartu Keluarga milik masyarakat tersebut. Berikut wawancara dengan Ibu Fariawati (40) selaku masyarakat yang kurang mampu.

Waktu itu pertama saya di kunjungi oleh pak RT untuk dimintai foto ktp, kartu keluarga dan juga saya 
ditannya-tanya soal kegiatan saya sehari-hari, dan barang-barang apa saja yang saya miliki. Terus setelah saya ditanya-tanya pak $R T$ langsung memberitahukan bahwa tujuan dia datang dirumah karena ada arahan dari pemerintah untuk dia memberitahukan bahwa ada bantuan dari Dinas Sosial, bantuan yang diberikan yaitu berupa sembako misalnya beras, minyak, dan telur satu rak.

Dari hasil wawancara diatas dapat disimpukan bahwa, dalam melakukan pendataan awalnya dari tingkat RT, karena ada arahan dari pemerintah untuk diberikan bantuan bagi masyarakat yang kurang mampu. Selain itu Waode Afara manamba, bahwa:

Pertama pendataan kita dikasih dulu formulir sama TKSK, terus itu kita disuruh isi formulir terus saya ditanya juga bilang ini kita mendata tujuannya sebenarnya karena ada bantuan dari kementrian sosial. Tapikan tidak semua orang mau dikasih bantuan dia pilih-pilih juga katannya, karena banyak juga orang biar banyak uangnya tapi kalau ada bantuan suka mau juga dapat, jadi harus betulpi katannya dia data baik-baik supaya tidak sembarangan juga dikasih itu bantuan. Tapi sebelumnnya kita didata diminta memangmi foto kopi ktp sama kartu keluarga, karena walaupun layak terima bantuan kalau tidak ada katannya ktp sama kartu keluarga tidak bisa juga dikasih bantuan karena itu ktp sama kartu keluarga sebagai persayaratannya, supaya dia lihat juga katanya bilang ini orang datannya benar-benar ada dikelurahan.
Dari hasil wawancara diatas dapat disimpulkan bahwa, pendataan itu dilakukan TKSK dengan cara memberikan formulir untuk mengisi formulir. Kemduan TKSK menjelaskan maksud dan tujuan melakukan pendataan. Juga memberitahukan persyaratan untuk penyaluran bantuan itu harus mempunyuai kartu tanda penduduk (KTP) dan kartu keluarga.

\section{Fungsi Fasilitasi}

Mencari potensi adalah fungsi TKSK untuk menentukan potensi apa yang ada pada masyarakat yang kurang mampu yaitu fungsi pontensi yang dimilki orang tua ataupun anak muda bagi keluarga yang kurang mampu adalah membuat kue, menjahit, kuli bangunan, dan membuka bengkel. Kemudian Dinas Sosial memberikan dana agar berguna dengan baik, sehingga diharapankan dana yang telah diberikan sebagai modal usaha, mampu meningkatkan kesejahteraan hidup masyarakat yang memiliki keahlian. Berikut hasil wawancara dengan bapak Erdiansyah.

Awalnya keluarga yang kurang mampu diwanwancarai menganai apa keahlian atau pontensi yang mereka miliki yaitu menjual, membuat kue, menjahit, kuli bangunan, dan membuka bengkel atau servis motor. Melalui potensi tersebut merakapun digabungkan dalam satu kelompok, misalnya yang memiliki kemampuan menjual, maka dikelompakan dengan kemampuannya menjual juga. Pokonya dek dalam satu kelompok harus memiliki kemampuan yang sama, agar mudah dalam membuka usaha bersama.

Dari hasil wawancara diatas dapat disimpulkan bahwa TKSK berperan mencari potensi masyarakat yang kurang 
mampu kemudian dibuatkan kelompok, minimal sepuluh orang dalam satu kelompok yang mempunyai skil atau potensi yang sama, agar masyarakat yang kurang mapu tersebut dapat membuat usaha bersama.

Selain itu bapak Muis selaku tenaga kesejahteraan sosial kecamatan menembahkan bahwa:

Cara saya untuk mencari tahu potensi yang dimilki keluarga yang kurang mampu saya biasannya melakukan wawancara mengenai potensinya, yang dapat membuatnya berkembang dengan meraih tujuan agar dapat hidup layak.

Dari hasil wawancara diatas dapat disimpulakan bahwa ketika TKSK ingin mengetahui potensi klien atau keluarga yang tidak mampu biasanya TKSK melakukan iterview mengenai potensi mereka tersebut. Berikut wawancara dengan Ibu Nila (45) selaku keluarga yang tidak mampu.

Pertama saya dikunjungi oleh TKSK, saya ditanya soal potensi yang saya miliki, terus saya dikasih tahu bahwa tujuan yang mecari tahu potensi saya itu karena dia ingin membantu saya, sesuai dengan potensi yang saya miliki. Maka saya langsung menceritakan potensi yang bisa dan yang saya inginkan.

Dari hasil wawancara diatas dapat disimpulakan bahwa, TKSK berkunjung kerumah keluarga yang kurang mampu dan mencari tahu apa potensi yang dimiliki. Kemudian TKSK menjelaskan maksud dan tujuan dia mencari tahu potensi atau kemampuan yang dimiliki oleh kerluarga tersebut. Kemudian TKSK bisa mengusulkan bantuan sesuai potanesi yang dimiliki dan diinginkan, agar keluarga yang kurang mampu dapat memiliki modal usaha untuk berjualan.
Selain itu Ibu Wauku menambahkan bahwa:

Waktu saya dikunjungi saya ditanya oleh TKSK mengenai pekerjaan yang bisa saya lakukan, terus saya menceritakan bahwa saya bisa mengurut orang jika ada yang panggil saya dan juga saya biasanya jadi buruh cuci agar saya dapat uang itu hidupi anak saya. Jadi saya hanya bisa melakukan itu saja karena saya sudah tua. Kemudian saya juga ditanyakan harapan saya kepada pemerintah, lalu saya bilang saya ingin diperhatikan agar dapat diberi bantuan.

Dari hasil wawancara diatas dapat disimpulkan bahwa saat keluarga yang kurang mampu dikunjungi oleh tenaga kesejahteraan sosial kecamatan, TKSK menanyakan pekerjaan yang bisa dia lakukan. Kemudian menceritakan potensi yang dia miliki yaitu dapat mengurut seseorang jika ada yang memintanya untuk mengurut dan juga jadi buruh cuci, dan juga menceritakan bahwa dia hanya bisa melakukan potensi itu karena dia sudah tua.

\section{Faktor Pendorong dan Penghambat Pelaksanaan Peran Tenaga Kesejahteraan Sosial di Kecamatan Kota Kendari.}

A. Faktor Pendorong

1. Memberikan Kewenangan

Dinas Sosial Kota Kendari memberikan kewenangan kepada TKSK selaku pihak yang bekerja di lapisan terbawah masyarakat dan merupakan local community organization dalam memberikan pertolongan untuk menanggulangi sosial yang mereka temui dilapangan.

Menurut Wisnu Andrianto, (2012) dalam meningkatakn kesejahteraan masayarakat harus melibatkan segenap potensi yang ada dalam masyarakat. 
Beberapa aspek diantaranya dapat diketegahkan antara lain, untuk dapat menjalankan misi birokrasinya harus ditingkatkan kewenangannya sampai lapisan terendah, ditingkatkan kualitasnya agar benar-benar mampu memberikan bimbingan dan pemberdayaan masyarakat.

2. Motivasi

Bertekad untuk mendukung terwujudnya peningkatan kesejahteraan sosial dalam keluarga yang kurang mampu untuk membantu penyelanggarang kesejahteraan sosila di tingkat Kecamatan.

B. Faktor Penghambat

1. Wilayah Kerja Yang Terlalu Luas

Luasnya wilayah jangkuan kerja serta kurangnya sarana tranportasi dalam menjalankan tugas, menjadi faktor penghambat bagi tenaga Kesejahteraan Sosial Kecamatan dalam meningkatkan Kesejahteraan masyarakat. Dari hasil wawancara diatas dapat disimpulkan bahwa, TKSK mengaku kesulitan dalam meningkatkan kesejahteraan masyarakat, keluarga yang kurang mampu, dimana jarak mereka yang agak berjauhan dan tidak bisa berjalan kaki harus menggunakan tranportasi roda dua (motor) agar bisa menempuh satu persatu kelaurga yang kurang mampu tersebut.

2. Ketidak terbukaan masyarakat yang kurang mampu

Ketidak terbukaan masyarakat atau keluarga yang kurang mampu ekonominya, tidak ingin memberitahukan status yang dimilikinya. Dari hasil wawancara diatas dapat diketahui bahwa, dalam melaksanakan tugas TKSK terkadang mengalami hambatan dalam meningkatakan kesejahteraan masyarakat, dikarenakan ketidak terbukaan pemilik data sehingga TKSK sulit untuk menggali informasi tentang masalah yang di hadapi oleh keluarga yang kurang mampu tersebut.
Berdasrkan hasil penelitian yang penulis laksanakan tentang"Peran Tenaga Kesejahteraan Sosial Di Kecamatan Posia Dalam Mingkatkan Kesejahteraan Masyarakat. Dapat ditarik kesempulan sebagai berikut: 1) Peran TKSK dalam meningkatkan ekonomi terdapat pendataan dan validasi data. Pendataan adalah kegiatan untuk mengumpulkan data dan informasi dilakukan oleh Tenaga Kesejahteraan Sosial Kecamatan (TKSK) terhadap keluarga yang kurang mampu; 2) Mencari potensi keluarga yang kurang mampu adalah peran TKSK untuk menentukan potensi apa yang ada pada keluarga yang kurang mampu agar keluarga tersebut dapat meningkatkan sesuai potensi yang dimilikinya; 3) Melakukan koordinasi dengan pihak Dinas Sosial kota kendari adalah untuk menjaga, menciptakan, mendukung, dan memperkuat penyelenggaran kesejahteraan Sosial keluarga yang kurang mampu; 4) Membantu penyelenggaraan kesejahteraan sosial adalah uapaya yang terarah, terpadu dan berkelanjutan yang dilakukan TKSK dalam meningkatkan kesejahteraan masyarakat guna memenuhi kebutuhan dasar keluarga yang kurang mampu.

Faktor Pendorong Dalam

Meningkatkan Kesejahteraan Masyarakat adalahmasyarakat Kancamatan Posia Mudah untuk diberdayakan. Kemudian adanya kerja sama yang baik antara masyarakat dengan Tenaga Kesejahteraan Sosial. Adapun Faktor Penghambat Dalam Meningkatkan Kesejahteraan Masyarakat Di Kecamatan Poasia adalah disebabkan oleh Tenaga Kesejahteraan Sosial Kecamatan yang terlalu luas cangkupan wilayah kerjanya yang meliputi satu Kecamatan.

\section{DAFTAR PUSTAKA}

Barika (2013). "Pengaruh Pertumbuhan Ekonomi, Pengeluaran Pemerintah, 
Pengangguran dan Inflasi Terhadap Kemiskinan Di Provinsi Se-Sumatera. Jurnal Ekonomi Dan Perencanaan Pembangunan. Vol.05 No.01. ISSN : 1979 - 7338.

Damayanti, A. (2016). Implementasi Program Keluarga Harapan (PKH) Dalam Meningkatkan Kualitas Hidup Masyarakat.

Mahsunah, Durrotul. 2013. Analisis Pengaruh Jumlah Penduduk, Pendidikan dan Pengangguran terhadap Kemiskinan Di Jawa Timur. Skripsi. Fakultas Ekonomi, Unesa, Kampus Ketintang Surabaya.

Mendayagunakan Potensi Insting dan Kekuatan Emosi Anda, Bandung: Kaifa.

Nining Haslinda Zainal, Analisis Kesesuaian Tugas Pokok dan Fungsi dengan Kompetensi Pegawai pada Sekretariat Pemerintah Kota Makassar, Universitas Hasanuddin: Skripsi, 2008.

Pustaka.

Segal, Jeanne, (2000), Melejitkan Kepekaan Emosional: Cara Baru Praktis untuk

Soekanto, Soerjono, 2001. Sosiologi sebagai pengantar. Jakarta. PT. Raja Grafindo Persada.

Steers, Richard. M. (1985). Efektifitas Organisasi Kaidah Pei Laku (Ahli Bahasa Magdalena). Jakarta : Erlangga.

Suharto, Edi. 2006. Membangun Masyarakat Memberdayakan Rakyat. Bandung: Rafilka Aditama.

Suparlan (2006). Guru Sebagai Profesi, Yokyakarta: Hikayat Publishing.

Suud, Mohammad. 2006 Orientasi Kesejahteraan Sosial. Jakarta: Prestasi Taliziduhu. 1990. Pembangunan Masyarakat Mempersiapkan Masyarakat Tinggal Landas. Jakarta : PT Rineka Cipta. Zainal , Nining Haslinda . 2008.
Thoha , Miftah. 1997, Pembinaan Organisasi (Proses Diagnosa dan Intervensi), Jakarta : PT. Raja Grafindo Persada.

Wisnu Andrianto, (2012) Peran Tenaga Kesekahteraan Sosial Kecamatan Dalam Penaggulangan Masalah Kesejahteraan Sosial. 